\title{
Making a noble case for Till and McCulloch
}

\author{
Dreams \& Due Diligence: Till \\ and McCulloch's Stem Cell \\ Discovery and Legacy \\ Joe Sornberger \\ University of Toronto Press; 2011.
}

I $t$ was not long before I read this book that I first heard of Jim Till and Ernest McCulloch, the Toronto researchers who first observed hematopoietic stem cells in the 1960s. The existence of stem cells had been hypothesized, but Till and McCulloch showed that they existed. As a hematologist, I'm a little embarrassed that this important research had been unknown to me. Imagine a physicist who was unaware of Robert Andrew Milliken or a geneticist who had never heard of James D. Watson, Francis Crick and Rosalind Franklin! Sornberger wrote Dreams \& Due Diligence with the plain purpose of correcting this sort of anonymity and placing Till and $\mathrm{McCulloch}$ alongside Norman Bethune and Frederick Banting in the pantheon of Canadian medicine.

This is an ambitious goal for a slender book. In making his case, Sornberger goes beyond simply describing

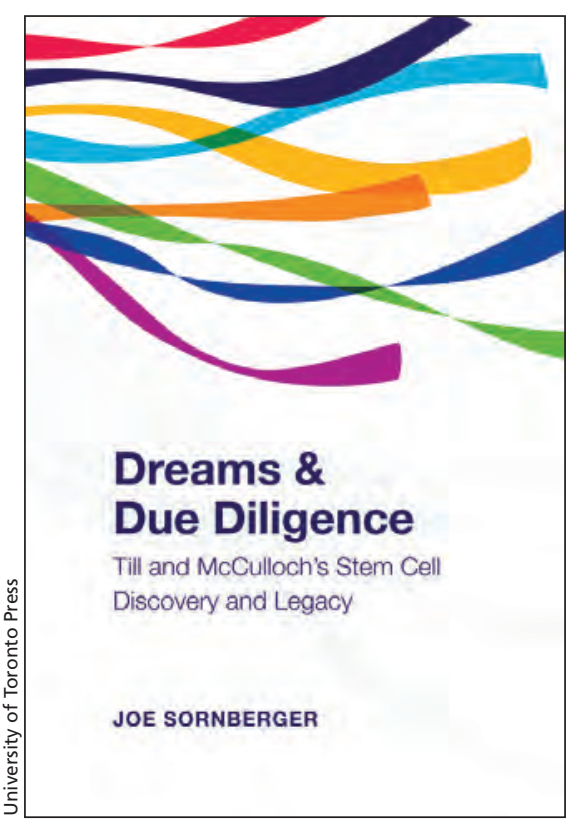

committee for not having made laureates of these Canadian scientists.

As he goes about his task, Sornberger is at his best as a science writer, and Till and McCulloch's work is described with an economic clarity. $\mathrm{He}$ is less comfortable writing about clinical medicine, and when he gets to describing personalities - those of Till, McCulloch or any number of sci-

\section{Sornberger is obsessed with the eminence he feels Till and McCulloch deserve.}

Till and McCulloch's important experiments; he details their academic genealogy, surveys subsequent work made possible by their discovery, and speculates on the possible uses of stemcell science in the not-too-distant future. He finishes with what is essentially a chastisement of the Nobel Prize entists who are their academic de scendants - Sornberger stalls at superficialities. Even his two main subjects are throughout the victims of a narrative that asserts an easy dichotomy between them: McCulloch the energetic Torontonian and Till the pragmatic prairie boy (they are repre- sented by "dreams" and "due diligence," respectively, in the title). After beginning with likening the pair to Bert and Ernie, Sornberger only rarely gets past this sort of facile juxtaposition to reveal character. The result is a sometimes wooden read that would have been livelier if, for example, we heard more about the "Bun" McCulloch who was known to throw chalk at people.

But this is a book about prestige, not character. In fact, Sornberger is fairly obsessed, not only with the eminence he feels Till and McCulloch deserve, but with prestige in general. He speaks of research institutions as one would royal palaces, drops the names of scientific journals like they were movie stars, and seems personally offended by the Nobel snub, which is at least halfuncorrectable now: McCulloch died in 2011, and there are no posthumous nominations for the Nobel.

As a reader, either you care about such things, or you don't. One suspects Till and McCulloch are in the latter camp: Sornberger provides no example of either man complaining with any energy about the Nobel issue, and their first important paper appeared in the lowly journal Radiation Research, rather than a marquee publication. Perhaps in this obscure beginning, Sornberger might take heart: it is possible that a book from an academic press might be the first step in rescuing his subjects from anonymity.

\section{Paul Moorehead MD}

Research fellow

Pathology and Molecular Medicine

Queen's University

Kingston, Ont.

CMAJ 2012. DOI:10.1503/cmaj.120307 